JURNAL SELAT

Volume. 8 Nomor. 2, Mei 2021. p - 2354-8649 I e - 2579-5767

Open Access at: http://ojs.umrah.ac.id/index.php/selat

DOI: https://doi.org/10.31629/selat.v8i2.3832

\title{
TANGGUNG JAWAB PELAKU USAHA TERHADAP STANDAR MUTU KOSMETIK BAGI KONSUMEN BERDASARKAN UNDANG-UNDANG NOMOR 8 TAHUN 1999 TENTANG PERLINDUNGAN KONSUMEN
}

\author{
Nofiardi ${ }^{1}$, Iriansyah ${ }^{2}$, Yetti ${ }^{3}$ \\ 1,2,3Program Studi Magister Ilmu Hukum Universitas Lancang Kuning \\ e-Mail: 1nofiardi.s2unilak@gmail.com, 2iriansyah@unilak.ac.id, ${ }^{3}$ yetti@unilak.ac.id
}

\begin{abstract}
Consumer protection is all efforts that ensure legal certainty to provide protection to consumers. This study aims to explain the responsibility of business actors to cosmetic quality standards for consumers based on Law Number 8 of 1999 concerning Consumer Protection. The method used in this research is normative legal research. In the decision of the Batam District Court Number 986/Pid.Sus/2016/PNBtm, Miau Kiuk alias Grace, an illegal cosmetic business actor, was sentenced to imprisonment for 4 months and 15 days and a fine of Rp. 5,000,000.00 without any accountability to the consumer. In the decision of the North Jakarta District Court Number 1616/Pid.Sus/2016/PNJktUtr, William Perkasa, an illegal cosmetic business actor, was sentenced to imprisonment for 1 year 6 months and a fine of Rp. 1,000,000,000.00 without any accountability to the consumer. In the decision of the Payakumbuh District Court Number 98/Pid.Sus/2017/PNPyh, Armen Dahlan, an illegal cosmetic business actor, was sentenced to prison for 1 month and a fine of Rp. 3,000,000.00 without any accountability to the consumer. Law enforcement officers should apply maximum sanctions to illegal cosmetic business actors accompanied by accountability to consumers who become victims as regulated in Law Number 8 of 1999 concerning Consumer Protection.
\end{abstract}

Keywords; Responsibility, Business Actor, Consumer.

\begin{abstract}
Abstrak
Perlindungan konsumen adalah segala upaya yang menjamin adanya kepastian hukum untuk memberi perlindungan kepada konsumen. Penelitian ini bertujuan untuk menjelaskan tanggung jawab pelaku usaha terhadap standar mutu kosmetik bagi konsumen berdasarkan Undang-Undang Nomor 8 Tahun 1999 tentang Perlindungan Konsumen. Metode yang digunakan dalam penelitian ini adalah penelitian hukum normatif. Dalam putusan Pengadilan Negeri Batam Nomor 986/Pid.Sus/2016/PNBtm, Miau Kiuk alias Grace, pelaku usaha kosmetik illegal, dipidana penjara selama 4 bulan 15 hari dan denda sebanyak Rp5.000.000,00 tanpa disertai adanya pertanggungjawaban kepada konsumen. Dalam putusan Pengadilan Negeri Jakarta Utara Nomor 1616/Pid.Sus/2016/PNJktUtr, William Perkasa, pelaku usaha kosmetik illegal, dipidana penjara selama 1 tahun 6 bulan dan denda sebanyak Rp1.000.000.000,00 tanpa disertai adanya pertanggungjawaban kepada
\end{abstract}


konsumennya. Dalam putusan Putusan Pengadilan Negeri Payakumbuh Nomor 98/Pid.Sus/2017/PNPyh, Armen Dahlan, pelaku usaha kosmetik illegal, dipidana penjara selama 1 bulan dan denda sebanyak Rp3.000.000,00 tanpa disertai adanya pertanggungjawaban kepada konsumennya. Aparat penegak hukum seharusnya menerapkan sanksi maksimal kepada pelaku usaha kosmetik illegal disertai adanya pertanggungjawaban kepada konsumen yang menjadi korban sebagaimana yang diatur dalam Undang-Undang Nomor 8 Tahun 1999 tentang Perlindungan Konsumen.

Kata kunci; Tanggung Jawab, Pelaku Usaha, Konsumen.

\section{PENDAHULUAN}

Konsumen adalah setiap orang pemakai barang dan/atau jasa yang tersedia dalam masyarakat, baik bagi kepentingan diri sendiri, kepentingan keluarga, kepentingan orang lain, maupun kepentingan makhluk hidup lain serta barang dan/atau jasa tersebut tidak untuk diperdagangkan. ${ }^{1}$ Pembangunan nasional bertujuan untuk mewujudkan suatu masyarakat yang adil dan makmur yang merata secara material dan spiritual dalam era demokrasi ekonomi berdasarkan Pancasila dan UUD 1945. Pembangunan perekonomian nasional pada era globalisasi harus dapat mendukung tumbuh dan berkembangnya dunia usaha sehingga para pelaku usaha mampu menghasilkan beraneka barang dan/atau jasa yang memiliki kandungan teknologi yang dapat meningkatkan kesejahteraan masyarakat banyak sekaligus masyarakat mendapatkan kepastian atas barang dan/atau jasa yang diperoleh dari perdagangan tanpa mengakibatkan kerugian bagi masyarakat. ${ }^{2}$

Perlindungan konsumen merupakan bagian yang tidak terpisahkan dari kegiatan bisnis yang sehat. Dalam kegiatan bisnis yang sehat, terdapat keseimbangan dalam perlindungan hukum antara produsen dan konsumen. Tidak adanya perlindungan yang seimbang menyebabkan konsumen berada pada posisi yang lemah, terlebih apabila produk yang dihasilkan oleh produsen merupakan jenis produk yang jumlahnya terbatas, maka produsen dapat menyalahgunakan posisinya yang monopolistis tersebut. Hal ini tentu saja akan merugikan konsumen. Kerugian yang dialami oleh konsumen tersebut dapat timbul sebagai akibat dari adanya

\footnotetext{
${ }^{1}$ Celina Tri Siwi Kristiyanti. Hukum Perlindungan Konsumen. Jakarta: Sinar Grafika, 2011, hlm. 10.

2 Rosmawati. Pokok-pokok Hukum Perlindungan Konsumen. Jakarta: Kencana Prenada Media, 2018, hlm. 3.
} 
hubungan hukum berupa perjanjian bisnis antara produsen dan konsumen maupun akibat dari adanya pelanggaran hukum yang dilakukan oleh produsen. ${ }^{3}$

Selain disebabkan oleh wanprestasi karena adanya hubungan hukum berupa perjanjian bisnis antara produsen dan konsumen dan perbuatan melawan hukum karena adanya pelanggaran hukum yang dilakukan oleh produsen, kerugian yang dialami konsumen selama ini banyak disebabkan oleh kurang kritisnya konsumen terhadap produk yang dipasarkan sehingga kerugian yang dialami konsumen tidak hanya kerugian finansial saja, tetapi juga merugikan kesehatannya maupun keselamatan jiwanya. Potensi kerugian yang dialami oleh konsumen semakin bertambah apabila produk-produk yang beredar di tengah-tengah masyarakat bukan merek yang sudah terdaftar alias produk illegal. Kemungkinan tersebut dapat saja terjadi karena adanya globalisasi, terutama di bidang perdagangan, yang mengakibatkan berbagai produk dari negara-negara lain dapat dengan bebas masuk ke Indonesia. ${ }^{4}$

Dengan telah dibukanya perdagangan bebas di wilayah Asia Tenggara melalui China-ASEAN Free Trade Area (CAFTA) pada tahun 2010 dan Masyarakat Ekonomi ASEAN (MEA) pada tahun 2015, maka produk-produk dari negara China maupun produk-produk dari negara-negara ASEAN seperti Malaysia dan Thailand akan beredar dengan bebas di Indonesia. Semakin terbukanya pasar nasional sebagai akibat dari proses globalisasi ekonomi seharusnya dapat menjamin peningkatan kesejahteraan masyarakat serta menjamin kepastian atas kualitas dan keamanan barang dan/atau jasa yang diperoleh masyarakat dari pelaku usaha di pasar. ${ }^{5}$ Beredarnya produk-produk dari negara China maupun produk-produk dari negaranegara ASEAN seperti Malaysia dan Thailand di satu sisi mempunyai manfaat bagi masyarakat sebagai konsumen karena kebutuhan masyarakat terhadap barang dan/atau jasa yang bervariasi dapat terpenuhi serta semakin terbuka lebar kebebasan masyarakat untuk memilih beraneka jenis dan merek barang dan/atau jasa sesuai dengan keinginan dan kemampuannya. Di sisi lain, fenomena tersebut dapat mengakibatkan kedudukan antara pelaku usaha dan konsumen menjadi tidak

${ }^{3}$ Ahmadi Miru. Prinsip-prinsip Perlindungan Hukum bagi Konsumen di Indonesia. Jakarta: Rajawali Pers, 2013, hlm. 17.

4 Yusuf Shofie. Hukum Perlindungan Konsumen di Indonesia. Bandung: Citra Aditya Bakti, 2008, hlm. 46.

5 Zainal Asikin. Hukum Dagang. Jakarta: Rajawali Pers, 2016, hlm. 25. 
seimbang. Konsumen berada pada posisi yang lemah karena konsumen menjadi objek aktivitas bisnis oleh para pelaku usaha untuk mendapatkan keuntungan yang sebesar-besarnya.

Pada dasarnya, prinsip ekonomi pelaku usaha adalah mencari keuntungan yang sebesar-besarnya dengan modal yang sekecil-kecilnya. Prinsip ini sangat potensial merugikan hak-hak konsumen, baik secara langsung maupun tidak langsung. Oleh karena itu, negara mempunyai peran yang penting untuk melindungi masyarakat yang berada pada posisi yang lemah tersebut. Undang-Undang Nomor 8 Tahun 1999 tentang Perlindungan Konsumen menjelaskan bahwa perlindungan konsumen adalah segala upaya yang menjamin adanya kepastian hukum untuk memberi perlindungan kepada setiap orang pemakai barang dan/atau jasa yang tersedia dalam masyarakat, baik bagi kepentingan diri sendiri, kepentingan keluarga, kepentingan orang lain, maupun kepentingan makhluk hidup lain serta barang dan/atau jasa tersebut tidak untuk diperdagangkan. Masalah perlindungan konsumen tidak semata-mata permasalahan individu saja, tetapi sebenarnya merupakan masalah bersama, bahkan masalah nasional, karena semua orang adalah konsumen. Oleh karena itu, konsep perlindungan konsumen oleh negara artinya adalah pemerintah negara melindungi rakyat negara tersebut. ${ }^{6}$

Berdasarkan Pasal 4 Undang-Undang Nomor 8 Tahun 1999 tentang Perlindungan Konsumen disebutkan bahwa hak-hak konsumen di Indonesia adalah sebagai berikut:

1. Hak atas kenyamanan, keamanan, dan keselamatan dalam mengkonsumsi barang dan/atau jasa.

2. Hak untuk memilih barang dan/atau jasa serta mendapatkan barang dan/atau jasa tersebut sesuai dengan nilai tukar dan kondisi serta jaminan yang dijanjikan.

3. Hak atas informasi yang benar, jelas, dan jujur mengenai kondisi dan jaminan barang dan/atau jasa.

4. Hak untuk didengar pendapat dan keluhannya atas barang dan/atau jasa yang digunakan.

${ }^{6}$ Zulham. Hukum Perlindungan Konsumen. Jakarta: Kencana Prenada Media, 2016, hlm. 12. 
5. Hak untuk mendapatkan advokasi, perlindungan, dan upaya penyelesaian sengketa perlindungan konsumen secara patut.

6. Hak untuk mendapat pembinaan dan pendidikan konsumen.

7. Hak untuk diperlakukan atau dilayani secara benar dan jujur serta tidak diskriminatif berdasarkan suku, agama, budaya, daerah, pendidikan, kaya, miskin, dan status sosial lainnya.

8. Hak untuk mendapatkan kompensasi, ganti rugi, dan/atau penggantian apabila barang dan/atau jasa yang diterima tidak sesuai dengan perjanjian atau tidak sebagaimana mestinya.

9. Hak-hak yang diatur dalam peraturan perundang-undangan lainnya.

Kosmetik adalah bahan yang dimaksudkan untuk digunakan pada bagian luar tubuh manusia seperti epidermis, rambut, kuku, bibir dan organ genital bagian luar, atau gigi dan membran mukosa mulut untuk membersihkan, mewangikan, mengubah penampilan, dan/atau memperbaiki bau badan serta melindungi atau memelihara tubuh pada kondisi yang lebih baik. Pada saat sekarang ini, kosmetik seolah menjadi suatu kebutuhan pokok bagi masyarakat, terutama kaum perempuan di Indonesia. Iklan produk-produk kosmetik, baik produk kosmetik produksi dalam negeri maupun luar negeri, setiap hari silih berganti menghiasi layar televisi masyarakat menjanjikan berbagai keunggulannya masing-masing.

Undang-Undang Nomor 8 Tahun 1999 tentang Perlindungan Konsumen mengatur bahwa masyarakat berhak atas kenyamanan, berhak atas keamanan, dan berhak atas keselamatan dalam menggunakan kosmetik yang dibeli dari pelaku usaha. Sejalan dengan itu, Undang-Undang Nomor 8 Tahun 1999 tentang Perlindungan Konsumen juga mengatur bahwa masyarakat berhak atas informasi yang benar, berhak atas informasi yang jelas, dan berhak atas informasi yang jujur dari pelaku usaha mengenai kosmetik yang diperdagangkan, misalnya izin edar kosmetik dari Badan Pengawas Obat dan Makanan (BPOM) Republik Indonesia maupun bahan yang terkandung di dalam kosmetik tersebut. Oleh karena itu, pemerintah melarang peredaran produk-produk kosmetik yang tidak memiliki izin edar karena bahan yang terkandung di dalam kosmetik tersebut belum diuji sehingga berpotensi membahayakan bagi kesehatan masyarakat sebagai konsumen. 
Pelaku usaha adalah setiap orang perseorangan atau badan usaha, baik badan usaha yang berbentuk badan hukum maupun badan usaha yang bukan badan hukum, yang didirikan dan berkedudukan atau melakukan kegiatan dalam wilayah hukum Negara Republik Indonesia, baik sendiri maupun bersama-sama, melalui perjanjian menyelenggarakan kegiatan usaha dalam berbagai bidang ekonomi. ${ }^{7}$ Berdasarkan Pasal 7 Undang-Undang Nomor 8 Tahun 1999 tentang Perlindungan Konsumen disebutkan bahwa hak-hak konsumen di Indonesia adalah sebagai berikut:

1. Beritikad baik dalam melakukan kegiatan usaha.

2. Memberikan informasi yang benar, jelas, dan jujur mengenai kondisi dan jaminan barang dan/atau jasa serta memberi penjelasan penggunaan, perbaikan, dan pemeliharaannya.

3. Memperlakukan atau melayani konsumen secara benar dan jujur serta tidak diskriminatif berdasarkan suku, agama, budaya, daerah, pendidikan, kaya, miskin, dan status sosial lainnya.

4. Menjamin mutu barang dan/atau jasa yang diproduksi dan/atau diperdagangkan berdasarkan ketentuan standar mutu barang dan/atau jasa yang berlaku.

5. Memberi kesempatan kepada konsumen untuk menguji dan/atau mencoba barang dan/atau jasa tertentu serta memberi jaminan dan/atau garansi atas barang yang dibuat dan/atau yang diperdagangkan.

6. Memberi kompensasi, ganti rugi, dan/atau penggantian atas kerugian akibat penggunaan, pemakaian, dan pemanfaatan barang dan/atau jasa yang diperdagangkan.

7. Memberi kompensasi, ganti rugi, dan/atau penggantian apabila barang dan/atau jasa yang diterima atau dimanfaatkan tidak sesuai dengan perjanjian.

Pelaku usaha, baik produsen, distributor, maupun pedagang, bertanggung jawab memberikan ganti rugi atas kerusakan, pencemaran, dan/atau kerugian konsumen akibat mengkonsumsi barang dan/atau jasa yang dihasilkan atau diperdagangkan. Ganti rugi tersebut dapat berupa pengembalian uang atau penggantian barang dan/atau jasa yang sejenis dan setara nilainya atau perawatan

${ }^{7}$ Az Nasution. Hukum Perlindungan Konsumen; Suatu Pengantar. Jakarta: Diadit Media, 2014, hlm. 23. 
kesehatan dan/atau pemberian santunan yang sesuai dengan ketentuan peraturan perundang-undangan yang berlaku. Pemberian ganti rugi dilaksanakan dalam tenggang waktu 7 (tujuh) hari setelah tanggal transaksi. Namun, Undang-Undang Nomor 8 Tahun 1999 tentang Perlindungan Konsumen mengatur bahwa pemberian ganti rugi tidak menghapuskan kemungkinan adanya tuntutan pidana berdasarkan pembuktian lebih lanjut. Pembuktian terhadap ada atau tidaknya unsur pidana merupakan beban dan tanggung jawab pelaku usaha tanpa menutup kemungkinan bagi jaksa untuk melakukan pembuktian. Ketentuan ini dimaksudkan untuk menerapkan sistem beban pembuktian terbalik. ${ }^{8}$

Dalam putusan Pengadilan Negeri Batam Nomor 986/Pid.Sus/2016/PNBtm, Miau Kiuk alias Grace yang merupakan pelaku usaha kosmetik illegal didakwa dengan Pasal 197 Undang-Undang Nomor 36 Tahun 2009 tentang Kesehatan yang menegaskan bahwa setiap orang yang dengan sengaja memproduksi atau mengedarkan sediaan farmasi dan/atau alat kesehatan yang tidak memiliki izin edar dipidana dengan pidana penjara paling lama 15 (lima belas) tahun dan denda paling banyak Rp1.500.000.000,00 (satu miliar lima ratus juta rupiah). Namun, Miau Kiuk alias Grace hanya divonis pidana penjara selama 4 (empat) bulan 15 (lima belas) hari dan denda sebanyak Rp5.000.000,00 (lima juta rupiah) dengan ketentuan apabila denda tersebut tidak dibayar diganti dengan kurungan selama 1 (satu) bulan, tanpa disertai adanya pertanggungjawaban kepada konsumennya.

Dalam putusan Pengadilan Negeri Jakarta Utara Nomor 1616/Pid.Sus/2016/PNJktUtr, William Perkasa yang merupakan pelaku usaha kosmetik illegal didakwa dengan Pasal 197 Undang-Undang Nomor 36 Tahun 2009 tentang Kesehatan yang menegaskan bahwa setiap orang yang dengan sengaja memproduksi atau mengedarkan sediaan farmasi dan/atau alat kesehatan yang tidak memiliki izin edar dipidana dengan pidana penjara paling lama 15 (lima belas) tahun dan denda paling banyak Rp1.500.000.000,00 (satu miliar lima ratus juta rupiah) serta Pasal 142 Undang-Undang Nomor 18 Tahun 2012 tentang Pangan yang menegaskan bahwa pelaku usaha pangan yang dengan sengaja tidak memiliki izin edar terhadap setiap pangan olahan yang dibuat di dalam negeri atau yang diimpor untuk diperdagangkan dalam kemasan eceran dipidana dengan pidana penjara

${ }^{8}$ Shidarta. Hukum Perlindungan Konsumen Indonesia. Jakarta: Grasindo, 2006, hlm. 88. 
paling lama 2 (dua) tahun atau denda paling banyak Rp4.000.000.000,00 (empat miliar rupiah). Namun, William Perkasa hanya dipidana penjara selama 1 (satu) tahun 6 (enam) bulan dan denda sebanyak Rp1.000.000.000,00 (satu miliar rupiah) dengan ketentuan apabila denda tersebut tidak dibayar diganti dengan kurungan selama 4 (empat) bulan, tanpa disertai adanya pertanggungjawaban kepada konsumennya.

Dalam putusan Putusan Pengadilan Negeri Payakumbuh Nomor 98/Pid.Sus/2017/PNPyh, Armen Dahlan yang merupakan pelaku usaha kosmetik illegal didakwa dengan Pasal 197 Undang-Undang Nomor 36 Tahun 2009 tentang Kesehatan yang menegaskan bahwa setiap orang yang dengan sengaja memproduksi atau mengedarkan sediaan farmasi dan/atau alat kesehatan yang tidak memiliki izin edar dipidana dengan pidana penjara paling lama 15 (lima belas) tahun dan denda paling banyak Rp1.500.000.000,00 (satu miliar lima ratus juta rupiah). Namun, Armen Dahlan hanya dipidana penjara selama 1 (satu) bulan dan denda sebanyak Rp3.000.000,00 (tiga juta rupiah) dengan ketentuan apabila denda tersebut tidak dibayar diganti dengan kurungan selama 1 (satu) bulan, tanpa disertai adanya pertanggungjawaban kepada konsumennya.

Padahal berdasarkan Pasal 19 Ayat (1) dan Ayat (2) Undang-Undang Nomor 8 Tahun 1999 tentang Perlindungan Konsumen diatur bahwa pelaku usaha bertanggung jawab memberikan ganti rugi atas kerusakan, pencemaran, dan/atau kerugian konsumen akibat mengkonsumsi barang dan/atau jasa yang dihasilkan atau diperdagangkan berupa pengembalian uang atau penggantian barang dan/atau jasa yang sejenis dan setara nilainya atau perawatan kesehatan dan/atau pemberian santunan yang sesuai dengan ketentuan peraturan perundang-undangan yang berlaku.

Dari latar belakang masalah yang telah dijelaskan di atas, maka permasalahan yang dibahas dalam penelitian ini bagaimanakah tanggung jawab pelaku usaha terhadap standar mutu kosmetik bagi konsumen berdasarkan Undang-Undang Nomor 8 Tahun 1999 tentang Perlindungan Konsumen? 


\section{METODE}

Penelitian hukum adalah suatu kegiatan ilmiah yang didasarkan pada metode, sistematika, dan pemikiran tertentu yang bertujuan untuk mempelajari satu atau beberapa gejala hukum tertentu dengan jalan menganalisanya. ${ }^{9}$ Metode yang digunakan dalam penelitian ini adalah penelitian hukum normatif. Penelitian hukum normatif adalah suatu proses untuk menemukan aturan hukum, prinsip-prinsip hukum, maupun doktrin-doktrin hukum guna menjawab isu-isu hukum yang dihadapi. ${ }^{10}$ Sumber data yang digunakan dalam penelitian ini adalah data sekunder, yaitu data yang diperoleh dari peraturan perundang-undangan, jurnal-jurnal ilmiah, dan literatur hukum. Teknik pengumpulan data yang digunakan dalam penelitian ini adalah studi kepustakaan, sedangkan teknik analisis data yang digunakan dalam penelitian ini adalah analisis kualitatif.

\section{PEMBAHASAN}

Perlindungan konsumen adalah segala upaya yang menjamin adanya kepastian hukum untuk memberi perlindungan kepada setiap orang pemakai barang dan/atau jasa yang tersedia dalam masyarakat, baik bagi kepentingan diri sendiri, kepentingan keluarga, kepentingan orang lain, maupun kepentingan makhluk hidup lain serta barang dan/atau jasa tersebut tidak untuk diperdagangkan. Asas-asas perlindungan konsumen di Indonesia sebagaimana yang diatur dalam Undang-Undang Nomor 8 Tahun 1999 tentang Perlindungan Konsumen yaitu sebagai berikut:

\section{Asas Manfaat}

Asas Manfaat dimaksudkan untuk mengamanatkan bahwa segala upaya dalam penyelenggaraan perlindungan konsumen harus memberikan manfaat sebesar-besarnya bagi kepentingan konsumen dan pelaku usaha secara keseluruhan.

2. Asas Keadilan

Asas Keadilan dimaksudkan agar partisipasi seluruh rakyat dapat diwujudkan secara maksimal dan memberikan kesempatan kepada

\footnotetext{
${ }_{9}^{9}$ Soerjono Soekanto. Pengantar Penelitian Hukum. Jakarta: UI Press, 2007, hlm. 40.

10 Peter Mahmud Marzuki. Penelitian Hukum. Jakarta: Kencana Prenada Media, 2011, hlm. 28.
} 
konsumen dan pelaku usaha untuk memperoleh haknya dan melaksanakan kewajibannya secara adil.

3. Asas Keseimbangan

Asas Keseimbangan dimaksudkan untuk memberikan keseimbangan antara kepentingan konsumen, kepentingan pelaku usaha, dan kepentingan pemerintah dalam arti material dan spiritual.

4. Asas Keamanan dan Keselamatan Konsumen

Asas Keamanan dan Keselamatan Konsumen dimaksudkan untuk memberikan jaminan atas keamanan dan keselamatan kepada konsumen dalam penggunaan, pemakaian, dan pemanfaatan barang dan/atau jasa yang dikonsumsi atau digunakan.

5. Asas Kepastian Hukum

Asas Kepastian Hukum dimaksudkan agar baik pelaku usaha maupun konsumen menaati hukum dan memperoleh keadilan dalam penyelenggaraan perlindungan konsumen, serta negara menjamin kepastian hukum. ${ }^{11}$

Tujuan perlindungan konsumen di Indonesia sebagaimana yang diatur dalam Undang-Undang Nomor 8 Tahun 1999 tentang Perlindungan Konsumen yaitu sebagai berikut:

1. Meningkatkan kesadaran, kemampuan, dan kemandirian konsumen untuk melindungi diri.

2. Mengangkat harkat dan martabat konsumen dengan cara menghindarkannya dari ekses negatif pemakaian barang dan/atau jasa.

3. Meningkatkan pemberdayaan konsumen dalam memilih, menentukan, dan menuntut hak-haknya sebagai konsumen.

4. Menciptakan sistem perlindungan konsumen yang mengandung unsur kepastian hukum dan keterbukaan informasi serta akses untuk mendapatkan informasi.

11 Yoanes, Tomy, Iriansyah, dan M. Yusuf Daeng. "Perlindungan Konsumen terhadap Peredaran Produk yang Tidak Mencantumkan Informasi dalam Bahasa Indonesia”. Jurnal Cendekia Hukum, 2021: Volume 6, Nomor 2, hlm. 249-250. 
5. Menumbuhkan kesadaran pelaku usaha mengenai pentingnya perlindungan konsumen sehingga tumbuh sikap yang jujur dan bertanggung jawab dalam berusaha.

6. Meningkatkan kualitas barang dan/atau jasa yang menjamin kelangsungan usaha produksi barang dan/atau jasa, kesehatan, kenyamanan, keamanan, dan keselamatan konsumen. ${ }^{12}$

Berdasarkan Pasal 19 Ayat (1) dan Ayat (2) Undang-Undang Nomor 8 Tahun 1999 tentang Perlindungan Konsumen diatur bahwa pelaku usaha bertanggung jawab memberikan ganti rugi atas kerusakan, pencemaran, dan/atau kerugian konsumen akibat mengkonsumsi barang dan/atau jasa yang dihasilkan atau diperdagangkan berupa pengembalian uang atau penggantian barang dan/atau jasa yang sejenis dan setara nilainya atau perawatan kesehatan dan/atau pemberian santunan yang sesuai dengan ketentuan peraturan perundang-undangan yang berlaku.

Dalam putusan Pengadilan Negeri Batam Nomor 986/Pid.Sus/2016/PNBtm, Miau Kiuk alias Grace yang merupakan pelaku usaha kosmetik illegal ditangkap oleh pihak kepolisian dan divonis bersalah oleh hakim karena Miau Kiuk alias Grace terbukti melanggar Pasal 197 Undang-Undang Nomor 36 Tahun 2009 tentang Kesehatan yaitu memperdagangkan kosmetik illegal kepada masyarakat dengan merek:

1. Fatloss Slimming Beauty 9 kotak

2. Show Slimming Traditional Herbal Green Tea 3 kotak

3. Lotion Kojic 2 botol

4. BSH Body Slim Herbal 2 kotak

5. Bust Firmar and Larger 2 kotak

6. USA Grow up Super 2 kotak

7. Breast Enhancer 2 Kotak

8. Gold L-Glutathione 2 botol

9. Animate E Facial Oil 3 kotak

10. L-Glutathione 2 botol

12 Natah, Luh Cahya Bungan, dan Marwanto. "Perlindungan Hukum terhadap Konsumen yang Mengkonsumsi Produk Kosmetik Impor Illegal yang Mengandung Bahan Berbahaya”. Jurnal Kertha Semaya, 2020: Volume 8, Nomor 2, hlm. 219-220. 
11. Beauty Breast Essence 2 kotak

12. 3 Days 3 Centimetres 2 kotak

13. Naked 4 Urban Decay 4 kotak

14. Lipgloss Kiss Beauty 5 kotak

15. Animal Tiger Wrinkle Mask 7 kotak

16. Animal Dragon Shooting Mask 4 kotak

17. Esther Gold 2 kotak

18. Esther Transparant Beauty Soap Vitamin E 12 kotak

19. Temulawak Gold 2 kotak

20. Widya Whitening Soap Temulawak 7 kotak

21. Temulawak New Night Cream 10 kotak

22. Temulawak New Day and Night Cream 20 kotak

23. Temulawak New Transparant Whitening Beauty Soap 12 kotak

24. Collagen Plus Vitamin E 25 kotak

25. Collagen Plus Vitamin E Night Cream 21 kotak.

Berdasarkan Pasal 197 Undang-Undang Nomor 36 Tahun 2009 tentang Kesehatan yang menegaskan bahwa setiap orang yang dengan sengaja memproduksi atau mengedarkan sediaan farmasi dan/atau alat kesehatan yang tidak memiliki izin edar dipidana dengan pidana penjara paling lama 15 (lima belas) tahun dan denda paling banyak Rp1.500.000.000,00 (satu miliar lima ratus juta rupiah). Namun, Miau Kiuk alias Grace hanya divonis pidana penjara selama 4 (empat) bulan 15 (lima belas) hari dan denda sebanyak Rp5.000.000,00 (lima juta rupiah) dengan ketentuan apabila denda tersebut tidak dibayar diganti dengan kurungan selama 1 (satu) bulan, tanpa disertai adanya pertanggungjawaban kepada konsumennya.

Dalam putusan Pengadilan Negeri Jakarta Utara Nomor 1616/Pid.Sus/2016/PNJktUtr, William Perkasa yang merupakan pelaku usaha kosmetik illegal ditangkap oleh pihak kepolisian dan divonis bersalah oleh hakim karena William Perkasa terbukti melanggar Pasal 197 Undang-Undang Nomor 36 Tahun 2009 tentang Kesehatan dan Pasal 142 Undang-Undang Nomor 18 Tahun 2012 tentang Pangan yaitu memperdagangkan kosmetik illegal kepada masyarakat dengan merek:

1. DR.ERIC Skin \& Body Care 47 kotak 
2. Natural Bath Lavender 96 kotak

3. Natural Bath Blueberry 78 kotak

4. Natural Bath Kelapa 58 kotak

5. Natural Bath Lemon 50 kotak

6. Serum Korea White Night Cream 96 kotak

7. BSH Body Slim Herbal 400 kotak

8. Whitening Mask Powder 10 kotak

9. Bounce up Pact 6 kotak

10. Botanical Slimming 5 kotak

11. Belly Wing 20 kotak

12. Masker Bibir 50 kotak

13. BSH Body Slim Herbal Kapsul 7 kotak

14. Emilay Whitening Clear Sport 73 kotak

15. Groosia Cream 31 kotak

16. Clear Dark 17 kotak

17. Eluta Panacea Body Lotion 7 kotak.

Berdasarkan Pasal 197 Undang-Undang Nomor 36 Tahun 2009 tentang Kesehatan yang menegaskan bahwa setiap orang yang dengan sengaja memproduksi atau mengedarkan sediaan farmasi dan/atau alat kesehatan yang tidak memiliki izin edar dipidana dengan pidana penjara paling lama 15 (lima belas) tahun dan denda paling banyak Rp1.500.000.000,00 (satu miliar lima ratus juta rupiah) serta Pasal 142 Undang-Undang Nomor 18 Tahun 2012 tentang Pangan yang menegaskan bahwa pelaku usaha pangan yang dengan sengaja tidak memiliki izin edar terhadap setiap pangan olahan yang dibuat di dalam negeri atau yang diimpor untuk diperdagangkan dalam kemasan eceran dipidana dengan pidana penjara paling lama 2 (dua) tahun atau denda paling banyak Rp4.000.000.000,00 (empat miliar rupiah). Namun, William Perkasa hanya dipidana penjara selama 1 (satu) tahun 6 (enam) bulan dan denda sebanyak Rp1.000.000.000,00 (satu miliar rupiah) dengan ketentuan apabila denda tersebut tidak dibayar diganti dengan kurungan selama 4 (empat) bulan, tanpa disertai adanya pertanggungjawaban kepada konsumennya.

Dalam putusan Putusan Pengadilan Negeri Payakumbuh Nomor 98/Pid.Sus/2017/PNPyh, Armen Dahlan yang merupakan pelaku usaha kosmetik 
illegal ditangkap oleh pihak kepolisian dan divonis bersalah oleh hakim karena Armen Dahlan terbukti melanggar Pasal 197 Undang-Undang Nomor 36 Tahun 2009 tentang Kesehatan yaitu memperdagangkan kosmetik illegal kepada masyarakat dengan merek:

1. MAC Eyeshadow \& Blush 168 pcs

2. MAC Rogue Fashion Color 60 pcs

3. Powder Blush 24 pcs

4. Temulawak Two Way Cake 12 pcs

5. Super DR Quality Gold Cream 264 pcs

6. Esther Whitening Day and Night 216 pcs

7. Naturgo Mask 20 kotak

8. La Widya Temulawak 24 pcs

9. Collagen Cream 24 pcs

10. Ling Zhi Day Cream 348 pcs.

Berdasarkan Pasal 197 Undang-Undang Nomor 36 Tahun 2009 tentang Kesehatan yang menegaskan bahwa setiap orang yang dengan sengaja memproduksi atau mengedarkan sediaan farmasi dan/atau alat kesehatan yang tidak memiliki izin edar dipidana dengan pidana penjara paling lama 15 (lima belas) tahun dan denda paling banyak Rp1.500.000.000,00 (satu miliar lima ratus juta rupiah). Namun, Armen Dahlan hanya dipidana penjara selama 1 (satu) bulan dan denda sebanyak Rp3.000.000,00 (tiga juta rupiah) dengan ketentuan apabila denda tersebut tidak dibayar diganti dengan kurungan selama 1 (satu) bulan, tanpa disertai adanya pertanggungjawaban kepada konsumennya.

Padahal berdasarkan Pasal 19 Ayat (1) dan Ayat (2) Undang-Undang Nomor 8 Tahun 1999 tentang Perlindungan Konsumen diatur bahwa pelaku usaha bertanggung jawab memberikan ganti rugi atas kerusakan, pencemaran, dan/atau kerugian konsumen akibat mengkonsumsi barang dan/atau jasa yang dihasilkan atau diperdagangkan berupa pengembalian uang atau penggantian barang dan/atau jasa yang sejenis dan setara nilainya atau perawatan kesehatan dan/atau pemberian santunan yang sesuai dengan ketentuan peraturan perundang-undangan yang berlaku. 
Faktor utama yang menjadi kelemahan konsumen adalah tingkat kesadaran konsumen akan haknya masih rendah. Hal ini terutama disebabkan oleh rendahnya pendidikan konsumen. Oleh karena itu, Undang-Undang Nomor 8 Tahun 1999 tentang Perlindungan Konsumen dimaksudkan menjadi landasan hukum yang kuat bagi pemerintah dan lembaga perlindungan konsumen swadaya masyarakat untuk melakukan upaya pemberdayaan konsumen melalui pembinaan dan pendidikan konsumen. ${ }^{13}$ Upaya pemberdayaan konsumen penting karena tidak mudah mengharapkan kesadaran pelaku usaha yang pada dasarnya prinsip ekonomi pelaku usaha adalah mendapat keuntungan yang semaksimal mungkin dengan modal seminimal mungkin. Prinsip ini sangat potensial merugikan kepentingan konsumen, baik secara langsung maupun tidak langsung. Atas dasar kondisi tersebut, perlu upaya pemberdayaan konsumen melalui pembentukan undang-undang yang dapat melindungi kepentingan konsumen secara integratif dan komprehensif serta dapat diterapkan secara efektif di masyarakat. ${ }^{14}$

Piranti hukum yang melindungi konsumen tidak dimaksudkan untuk mematikan usaha para pelaku usaha, tetapi justru sebaliknya, perlindungan konsumen dapat mendorong iklim berusaha yang sehat yang mendorong lahirnya perusahaan yang tangguh dalam menghadapi persaingan melalui penyediaan barang dan/atau jasa yang berkualitas. Di samping itu, Undang-Undang Nomor 8 Tahun 1999 tentang Perlindungan Konsumen dalam pelaksanaannya tetap memberikan perhatian khusus kepada pelaku usaha kecil dan pelaku usaha menengah. Hal ini dilakukan melalui upaya pembinaan dan penerapan sanksi atas pelanggarannya. Undang-Undang Republik Indonesia Nomor 8 Tahun 1999 tentang Perlindungan Konsumen dirumuskan dengan mengacu pada filosofi pembangunan nasional bahwa pembangunan nasional termasuk pembangunan hukum yang memberikan perlindungan terhadap konsumen adalah dalam rangka membangun manusia Indonesia seutuhnya yang berlandaskan pada falsafah kenegaraan Republik Indonesia yaitu dasar negara Pancasila dan konstitusi negara UUD 1945.

13 Hamid, Abdul. "Penegakan Hukum terhadap Peredaran Sediaan Farmasi (Kosmetik) Tanpa Izin Edar dari BPOM di Provinsi Riau". Jurnal Equitable, 2018: Volume 3, Nomor 2, hlm. 88-89.

14 Jaya, Febri. "Tinjauan Yuridis terhadap Pemasaran Kosmetik Illegal Secara Online di Indonesia”. Journal of Judicial Review, 2020: Volume 22, Nomor 1, hlm. 110-111. 
Berdasarkan Pasal 30 Undang-Undang Nomor 8 Tahun 1999 tentang Perlindungan Konsumen disebutkan bahwa selain pemerintah, pengawasan terhadap penyelenggaraan perlindungan konsumen diselenggarakan oleh masyarakat dan lembaga perlindungan konsumen swadaya masyarakat. Artinya, pemerintah dapat melibatkan masyarakat secara individu maupun lembaga perlindungan konsumen swadaya masyarakat seperti YLKI (Yayasan Lembaga Konsumen Indonesia).

Apabila masyarakat sebagai konsumen ada yang merasa dirugikan akibat memakai produk kosmetik yang mengandung zat yang berbahaya bagi kesehatan, maka berdasarkan Pasal 45 Undang-Undang Nomor 8 Tahun 1999 tentang Perlindungan Konsumen disebutkan bahwa konsumen tersebut dapat menggugat pelaku usaha melalui Badan Penyelesaian Sengketa Konsumen (BPSK) atau melalui pengadilan negeri. Penyelesaian sengketa konsumen dapat ditempuh melalui pengadilan atau di luar pengadilan berdasarkan pilihan sukarela para pihak yang bersengketa. Penyelesaian sengketa di luar pengadilan tidak menghilangkan tanggung jawab pidana para pihak. Apabila telah dipilih upaya penyelesaian sengketa konsumen di luar pengadilan, gugatan melalui pengadilan hanya dapat ditempuh apabila upaya penyelesaian sengketa konsumen di luar pengadilan dinyatakan tidak berhasil oleh salah satu pihak atau oleh para pihak yang bersengketa. 15

Pasal 46 Ayat (1) Undang-Undang Nomor 8 Tahun 1999 tentang Perlindungan Konsumen mengatur bahwa gugatan atas pelanggaran pelaku usaha dapat dilakukan oleh:

1. Seorang konsumen yang dirugikan atau ahli waris yang bersangkutan.

2. Sekelompok konsumen yang mempunyai kepentingan yang sama.

3. Lembaga perlindungan konsumen swadaya masyarakat yang memenuhi syarat, yaitu berbentuk badan hukum atau yayasan, yang dalam anggaran dasarnya menyebutkan dengan tegas bahwa tujuan didirikannya organisasi tersebut adalah untuk kepentingan perlindungan konsumen dan telah melaksanakan kegiatan sesuai dengan anggaran dasarnya.

15 Utama, Andrew Shandy. "Kepercayaan Masyarakat terhadap Penegakan Hukum di Indonesia". Jurnal Ensiklopedia Social Review, 2019: Volume 1, Nomor 3, hlm. 313. 
4. Pemerintah dan/atau instansi terkait apabila barang dan/atau jasa yang dikonsumsi atau dimanfaatkan mengakibatkan kerugian materi yang besar dan/atau korban yang tidak sedikit.

Pasal 46 Ayat (2) Undang-Undang Nomor 8 Tahun 1999 tentang Perlindungan Konsumen mengatur bahwa gugatan yang diajukan oleh sekelompok konsumen, lembaga perlindungan konsumen swadaya masyarakat, atau pemerintah diajukan kepada peradilan umum.

Berdasarkan Pasal 47 Undang-Undang Nomor 8 Tahun 1999 tentang Perlindungan Konsumen diatur bahwa penyelesaian sengketa konsumen di luar pengadilan melalui Badan Penyelesaian Sengketa Konsumen (BPSK) diselenggarakan untuk mencapai kesepakatan mengenai bentuk dan besarnya ganti rugi dan/atau mengenai tindakan tertentu untuk menjamin tidak akan terjadi kembali atau tidak akan terulang kembali kerugian yang diderita oleh konsumen. Berdasarkan Pasal 48 Undang-Undang Nomor 8 Tahun 1999 tentang Perlindungan Konsumen diatur bahwa penyelesaian sengketa konsumen melalui pengadilan mengacu pada ketentuan tentang peradilan umum yang berlaku dengan memperhatikan ketentuan dalam Pasal 45 Undang-Undang Nomor 8 Tahun 1999 tentang Perlindungan Konsumen.

Selain itu, Undang-Undang Nomor 8 Tahun 1999 tentang Perlindungan Konsumen juga mengatur mengenai sanksi pidana bagi pelaku usaha, baik produsen, distributor, maupun pedagang, yang menjual produk kosmetik illegal dan mengandung zat yang berbahaya bagi kesehatan. Berdasarkan Pasal 62 UndangUndang Nomor 8 Tahun 1999 tentang Perlindungan Konsumen dapat dipidana dengan pidana penjara paling lama 5 (lima) tahun atau pidana denda paling banyak Rp2.000.000.000,- (dua miliar rupiah). Selain sanksi pidana, pelaku usaha, baik produsen, distributor, maupun pedagang, yang menjual produk kosmetik illegal dan mengandung zat yang berbahaya bagi kesehatan berdasarkan Pasal 63 UndangUndang Nomor 8 Tahun 1999 tentang Perlindungan Konsumen dapat dijatuhkan hukuman tambahan berupa:

1. Perampasan produk apabila masih diproduksi, didistribusikan, maupun dijual ke masyarakat. 
2. Pembayaran ganti rugi apabila ada masyarakat yang merasa sakit dan dirugikan karena telah terlanjur mengkonsumsi produk makanan kadaluwarsa.

3. Perintah penghentian kegiatan produksi, distribusi, dan penjualan produk yang telah merugikan masyarakat.

4. Kewajiban penarikan produk dari peredaran.

5. Pencabutan izin usaha, baik produsen, distributor, maupun pedagang yang menjual produk makanan kadaluwarsa.

Penegakan hokum terhadap tindak pidana dalam Undang-Undang Nomor 8 Tahun 1999 tentang Perlindungan Konsumen dilaksanakan oleh Kepolisian Negara Republik Indonesia. Berdasarkan Pasal 16 Undang-Undang Nomor 2 Tahun 2002 tentang Kepolisian Negara Republik Indonesia disebutkan bahwa dalam rangka melaksanakan tugas pokok dan tugas-tugasnya di bidang proses pidana, Kepolisian Negara Republik Indonesia berwenang untuk:

1. Melakukan penangkapan, penahanan, penggeledahan, dan penyitaan.

2. Melarang setiap orang meninggalkan atau memasuki tempat kejadian perkara untuk kepentingan penyidikan.

3. Membawa dan menghadapkan orang kepada penyidik dalam rangka penyidikan.

4. Menyuruh berhenti orang yang dicurigai dan menanyakan serta memeriksa tanda pengenal diri.

5. Melakukan pemeriksaan dan penyitaan surat.

6. Memanggil orang untuk didengar dan diperiksa sebagai tersangka atau saksi.

7. Mendatangkan orang ahli yang diperlukan dalam hubungannya dengan pemeriksaan perkara.

8. Mengadakan penghentian penyidikan.

9. Menyerahkan berkas perkara kepada penuntut umum.

10. Mengajukan permintaan secara langsung kepada pejabat imigrasi yang berwenang di tempat pemeriksaan imigrasi dalam keadaan mendesak atau mendadak untuk mencegah atau menangkal orang yang disangka melakukan tindak pidana. 
11. Memberi petunjuk dan bantuan penyidikan kepada Penyidik Pegawai Negeri Sipil (PPNS) serta menerima hasil penyidikan Penyidik Pegawai Negeri Sipil (PPNS) untuk diserahkan kepada penuntut umum.

12. Mengadakan tindakan lain menurut hukum yang bertanggung jawab, yaitu tindakan penyelidikan dan penyidikan yang dilaksanakan jika memenuhi syarat sebagai berikut:

a. Tidak bertentangan dengan suatu aturan hukum.

b. Selaras dengan kewajiban hukum yang mengharuskan tindakan tersebut dilakukan.

c. Harus patut, masuk akal, dan termasuk dalam lingkungan jabatannya.

d. Pertimbangan yang layak berdasarkan keadaan yang memaksa.

e. Menghormati hak asasi manusia.

Selain Pejabat Polisi Negara Republik Indonesia, Pejabat Pegawai Negeri Sipil tertentu di lingkungan instansi pemerintah yang lingkup tugas dan tanggung jawabnya di bidang perlindungan konsumen juga diberi wewenang khusus sebagai penyidik sebagaimana dimaksud dalam Undang-undang Hukum Acara Pidana yang berlaku. Penyidik Pejabat Pegawai Negeri Sipil berwenang:

1. Melakukan pemeriksaan atas kebenaran laporan atau keterangan berkenaan dengan tindak pidana di bidang perlindungan konsumen.

2. Melakukan pemeriksaan terhadap orang atau badan hukum yang diduga melakukan tindak pidana di bidang perlindungan konsumen.

3. Meminta keterangan dan bahan bukti dari orang atau badan hukum sehubungan dengan peristiwa tindak pidana di bidang perlindungan konsumen.

4. Melakukan pemeriksaan atas pembukuan, catatan, dan dokumen lain berkenaan dengan tindak pidana di bidang perlindungan konsumen.

5. Melakukan pemeriksaan di tempat tertentu yang diduga terdapat bahan bukti serta melakukan penyitaan terhadap barang hasil pelanggaran yang dapat dijadikan bukti dalam perkara tindak pidana di bidang perlindungan konsumen.

6. Meminta bantuan ahli dalam rangka pelaksanaan tugas penyidikan tindak pidana di bidang perlindungan konsumen. 


\section{KESIMPULAN}

Dalam putusan Pengadilan Negeri Batam Nomor 986/Pid.Sus/2016/PNBtm, Miau Kiuk alias Grace yang merupakan pelaku usaha kosmetik illegal dipidana penjara selama 4 (empat) bulan 15 (lima belas) hari dan denda sebanyak Rp5.000.000,00 (lima juta rupiah) dengan ketentuan apabila denda tersebut tidak dibayar diganti dengan kurungan selama 1 (satu) bulan, tanpa disertai adanya pertanggungjawaban kepada konsumennya. Dalam putusan Pengadilan Negeri Jakarta Utara Nomor 1616/Pid.Sus/2016/PNJktUtr, William Perkasa yang merupakan pelaku usaha kosmetik illegal dipidana penjara selama 1 (satu) tahun 6 (enam) bulan dan denda sebanyak Rp1.000.000.000,00 (satu miliar rupiah) dengan ketentuan apabila denda tersebut tidak dibayar diganti dengan kurungan selama 4 (empat) bulan, tanpa disertai adanya pertanggungjawaban kepada konsumennya. Dalam putusan Putusan Pengadilan Negeri Payakumbuh Nomor 98/Pid.Sus/2017/PNPyh, Armen Dahlan yang merupakan pelaku usaha kosmetik illegal dipidana penjara selama 1 (satu) bulan dan denda sebanyak Rp3.000.000,00 (tiga juta rupiah) dengan ketentuan apabila denda tersebut tidak dibayar diganti dengan kurungan selama 1 (satu) bulan, tanpa disertai adanya pertanggungjawaban kepada konsumennya.

\section{DAFTAR PUSTAKA}

\section{Buku}

Asikin, Zainal. Hukum Dagang. Jakarta: Rajawali Pers, 2016.

Kristiyanti, Celina Tri Siwi. Hukum Perlindungan Konsumen. Jakarta: Sinar Grafika, 2011.

Marzuki, Peter Mahmud. Penelitian Hukum. Jakarta: Kencana Prenada Media, 2011

Miru, Ahmadi. Prinsip-prinsip Perlindungan Hukum bagi Konsumen di Indonesia. Jakarta: Rajawali Pers, 2013.

Nasution, Az. Hukum Perlindungan Konsumen; Suatu Pengantar. Jakarta: Diadit Media, 2014.

Rosmawati. Pokok-pokok Hukum Perlindungan Konsumen. Jakarta: Kencana Prenada Media, 2018.

Shidarta. Hukum Perlindungan Konsumen Indonesia. Jakarta: Grasindo, 2006. 
Shofie, Yusuf. Hukum Perlindungan Konsumen di Indonesia. Bandung: Citra Aditya Bakti, 2008.

Soekanto, Soerjono. Pengantar Penelitian Hukum. Jakarta: UI Press, 2007.

Zulham. Hukum Perlindungan Konsumen. Jakarta: Kencana Prenada Media, 2016.

\section{Artikel}

Angkasa, Rena Yulia, dan Ogiandhafiz Juanda. "Urgensi Victim Precipitation Dipertimbangkan oleh Hakim dalam Penjatuhan Putusan Pemidanaan". Jurnal Wawasan Yuridika, 2021: Volume 5, Nomor 1.

Dewi, Sandra, Fahrial, Andrew Shandy Utama, Idham Kholid, Budi Satria, dan Dhian Tyas Untari. "Small and Medium Enterprises (SMEs); The Strength of the Indonesian Economy". Psychology and Education Journal, 2020: Volume 59, Nomor 7.

Endri, Suryadi, dan Pery Rehendra Sucipta. "Proporsionalitas Putusan Hakim Berdasarkan Ide Keseimbangan”. Jurnal Selat, 2020: Volume 7, Nomor 2.

Hamid, Abdul. "Penegakan Hukum terhadap Peredaran Sediaan Farmasi (Kosmetik) Tanpa Izin Edar dari BPOM di Provinsi Riau". Jurnal Equitable, 2018: Volume 3, Nomor 2.

Jaya, Febri. "Tinjauan Yuridis terhadap Pemasaran Kosmetik Illegal Secara Online di Indonesia". Journal of Judicial Review, 2020: Volume 22, Nomor 1.

Natah, Luh Cahya Bungan, dan Marwanto. "Perlindungan Hukum terhadap Konsumen yang Mengkonsumsi Produk Kosmetik Impor Illegal yang Mengandung Bahan Berbahaya". Jurnal Kertha Semaya, 2020: Volume 8, Nomor 2.

Utama, Andrew Shandy. "Kepercayaan Masyarakat terhadap Penegakan Hukum di Indonesia". Jurnal Ensiklopedia Social Review, 2019: Volume 1, Nomor 3.

Utama, Andrew Shandy, Rizana, dan Tri Anggara Putra. “Tanggung Jawab Sosial Perusahaan PT Asia Forestama Raya di Kota Pekanbaru dan Penegakan Hukumnya". Pagaruyuang Law Journal, 2019: Volume 2, Nomor 2.

Wahyulina, Diah, dan Febry Chrisdanty. "Penegakan Hukum Sengketa Konsumen oleh BPSK untuk Pencegahan Pelanggaran Hak Konsumen". Jurnal Et-Tijarie, 2018: Volume 5, Nomor 2.

Yoanes, Tomy, Iriansyah, dan M. Yusuf Daeng. "Perlindungan Konsumen terhadap Peredaran Produk yang Tidak Mencantumkan Informasi dalam Bahasa Indonesia". Jurnal Cendekia Hukum, 2021: Volume 6, Nomor 2.

\section{Peraturan Perundang-undangan}

Undang-Undang Nomor 8 Tahun 1999 tentang Perlindungan Konsumen. 